\title{
A SOLAR DRYER PERFORMANCE OF ONION SLICES UNDER FAYOUM CLIMATIC CONDITIONS
}

\author{
H. S. Abdel-Galil ${ }^{*}$ and R. I. A. Mourad ${ }^{* *}$
}

\begin{abstract}
A solar drying unit was developed and constructed for drying onion slices under Fayoum conditions. The drying unit consists of a solar collector, which oriented and tilted with an optimum tilt angle and attached with drying chamber. The drying experiments were carried out to examine the effect of onion slice thicknesses $(3,6$ and $10 \mathrm{~mm})$ and airflow rate (2.4 and $\left.1.6 \mathrm{~m}^{3} . \mathrm{min}^{-1}\right)$ on the onion slices drying rate. The obtained results indicated that the daily average total solar radiation flux incident on the tilted solar collector surface $\left(7.32 \mathrm{kWh} . \mathrm{m}^{-2} . \mathrm{day}^{-1}\right)$ was greater than that incident on the horizontal surface $\left(6.13 \mathrm{kWh} . \mathrm{m}^{-2} . \mathrm{day}^{-1}\right)$ by $19.41 \%$. The higher air temperatures were obtained at the lower airflow rate $\left(1.6 \mathrm{~m}^{3} . \mathrm{min}^{-1}\right)$ whereas; the amount of heat gained to the air from the solar collector was relatively higher at the higher airflow rate as compared with the lower airflow rate. Consequently the higher efficiency of the solar collector was obtained at the higher airflow rate. The solar collector with the higher airflow rate increased the overall thermal efficiency by $12.56 \%$ as compared to the lower airflow rate. The moisture content of dried onion slices was strongly affected by the onion slices thickness and the airflow rate. The final moisture content of dried onion slices ranged from (6.8\% to $7.7 \%$ dry-basis) depending on the drying temperature cycle. Effect of the individual variables (airflow rate, onion slice thickness, moisture removed, and their interactions) on the drying rate was statistically analyzed. A forward step-wise regression technique was applied to arrive at a reasonable good best set of independent variables. The coefficient of determination $\left(R^{2}\right)$ was above 0.97 when comparing observed and predicted drying rate.
\end{abstract}

\section{INTRODUCTION}

bulb onions are considered to be one of the most important
vegetable crops in Fayoum Governorate, Egypt. In 2005, the total
planted area of onions in Fayoum is 13052 feddans which produce 
205569 tons yearly (15.75 ton/fed), while the total planted area in Egypt is 101385 feddans which produce 1301175 tons yearly (12.834 ton/ feddan). Thus, Fayoum represents $12.87 \%$ and 15.8 from the total planted area and the productivity of onions in Egypt, respectively (Agricultural statistics, 2006). Onions could be consumed fresh as in green salad or in many other forms (as bulbs for cooking and pickling consumption) and use in food processing. Essa and Gamea (2003) stored some of the bulb onions in a room at an ambient air temperature of $24{ }^{\circ} \mathrm{C}$, without any control of relative humidity and carbon dioxide $\left(\mathrm{CO}_{2}\right)$. They found that the mean puncture resistance and firmness were found to be decreased with storage time.

Hall (1980) reported that a drying period is required after harvesting when onions are removed from field with excess surface moisture. He, also indicated that when onions have surface moisture placed in storage case, relative humidity in the pile reached $100 \%$, thereby encouraging the growth of rot-causing organisms.

Sharma and Nath (1991) dried ten onion varieties ( $5 \mathrm{~mm}$ thick rings) in an air cabinet dryer $\left(65 \pm 2{ }^{\circ} \mathrm{C}\right)$ for seven hours. They indicated that dehydration reduced pyruvic acid, ascorbic acid and induced browning, while the extent of these changes depends upon the onion variety. Lewicki et al. (1998-a) studied the effect of drying mode in the drying kinetics of onion using onion slices $3 \mathrm{~mm}$ thick at $60{ }^{\circ} \mathrm{C}$ by convection. They mentioned that increasing air drying temperature increases the drying rate. They also, found that the effective diffusivity increases with increasing air drying temperature, but it is strongly dependent on the moisture content. Lewicki et al. (1998-b) used a forced convection dryer at $60{ }^{\circ} \mathrm{C}$ air drying temperature and $2 \mathrm{~m} / \mathrm{s}$ air velocity for drying two different onion varieties (Oporto and Blonska). Prior to drying process, onion slices were projected to the following treatments: (a) soaking in water, (b) dipping in starch solution supplement either with ascorbic acid or calcium chloride $\left(\mathrm{Ca}_{2}\right)$ and (c) dewatering by osmosis in sucrose solution, while dried raw onions without any treatment were used as a control. They found that both varieties and pretreatments of onions effected on the drying rate and the course of the drying process. They mentioned that soaking in water and dipping in starch either increase the 
drying rate and have no effect on the kinetics of the drying process. They also, concluded that supplementing the starch with ascorbic acid or calcium chloride $\left(\mathrm{Ca} \mathrm{Cl}_{2}\right)$ adversely affected the drying rate of onions. Al-Katary (2000) studied air-properties of a thin layer drying system for onion slices of $0.5 \mathrm{~mm}$ thick using drying air temperature of $60{ }^{\circ} \mathrm{C}, 10.5 \%$ relative humidity and airflow rate of $2.4 \mathrm{~m}^{3} / \mathrm{h}$. He concluded that properties of the exhaust drying air were suitable for reuse in the drying process after two hours from the beginning of the drying process. Thus, after two hours from the drying process, the exhaust air may pass through either the same onion samples or a subsequent one conserving about $80.45 \mathrm{MJ} / \mathrm{kg}$ of exhaust energy lost in the ambient air, consequently increasing the drying efficiency by $67.62 \%$ (from $18.38 \%$ to $86.0 \%$ ). Yaldiz and Ertekin (2001) employed a solar cabinet dryer (consisting of a solar heater and a drying cabinet) for drying five different vegetable crops; pumpkin, green pepper, stuffed pepper, green beans and onion. They concluded that, the drying air temperature could increase up to 46 ${ }^{\circ} \mathrm{C}$, but the drying air velocity had an important effect on the drying process. The drying time changed between 30.29 and 90.43 hours for the five different vegetables by the solar drying, but this drying time was between 48.59 and 121.81 hours for the natural sun drying. Sharma et al. (2005) used a laboratory scale infrared-convection dryer at infrared power levels of 300, 400 and $500 \mathrm{~W}$, drying air temperatures of 35,40 and $45{ }^{\circ} \mathrm{C}$ and inlet drying air velocities of $1.0,1.25$ and $1.5 \mathrm{~m} / \mathrm{s}$ for drying onion slices. They found that the drying time reduced by about 2.25 times by increasing infrared power from 300 to $500 \mathrm{~W}$, air temperatures from 35 to $50{ }^{\circ} \mathrm{C}$ and air velocity from 1.0 to $1.5 \mathrm{~m} / \mathrm{s}$. Effective diffusivity varied from $0.21 \times 10^{-10}$ to $1.57 \times 10^{-10} \mathrm{~m}^{2} . \mathrm{s}^{-1}$ and it was significantly influenced by infrared power and air temperature.

The main aim of this paper is to develop a solar drying unit to dry onion slices and to evaluate its thermal performance.

\section{MATERIALS AND METHODS}

\section{A. Solar dryer set-up:}

The solar drying unit was developed and constructed for drying onion slices in Abchway district, Fayoum, Egypt on August, 2008. The latitude 
and longitude angles for the specific location are $29.21 \mathrm{~N}$ and $30.40^{\circ}$, respectively. The drying unit consists of a solar collector attached with drying chamber. A schematic diagram for the drying unit of the experimental set-up is shown at (Fig. 1), and the following are details of the components:

1. Solar collector: A single flat-plate solar collector with airflow over the absorber was made of rectangular wooden box. It has a surface area of $0.66 \mathrm{~m}^{2}$ (1.0 m long, $0.66 \mathrm{~m}$ wide and $0.10 \mathrm{~m}$ thickness). The solar collector was painted from inside and outside surfaces using matt black paint. A fiber glass wool $\left(24 \mathrm{~kg} . \mathrm{m}^{-3}\right)$ with thickness of $0.05 \mathrm{~m}$ and a thermal conductivity of $0.045 \mathrm{~W} . \mathrm{m}^{-1} .{ }^{\circ} \mathrm{C}^{-1}$ were used to insulate the sides and bottom of the collector. Galvanized flat metal plate painted matt black which having absorpitivity and emissivity of 0.95 and 0.87 , respectively. This plate was also used as an absorber plate to absorb the maximum amount of solar energy. To minimize the reflection of radiation and reduce the heat loss by convection, a clear transparent plastic was situated to cover the solar collector. The solar collector has two ducts, which are used as an air inlet and outlet to facilitate the attachment of the solar collector to both the air fan and the drying chamber. A suction fan (150 mm diameter, model No.OC-15R, 220 Volt, 50 Hertz, Ocarina made) was put in the inlet duct in the front entrance of the solar collector to introduce the ambient air $\left(\mathrm{T}_{\mathrm{a}}\right)$ to it for heating and, then, passes through the drying chamber. The solar collector was orientated to face the south direction and tilted with a tilt angle $\left(\beta=15.7^{\circ}\right)$, which calculated by the following formula:

$\beta=$ Latitude angle $(\Phi)-$ solar declination angle $(\delta),\left({ }^{\circ}\right) \ldots . . .(1)$ Where:

$\Phi=$ Latitude angle at Abchway district, Fayoum is $29.21^{\circ} \mathrm{N}$.

$\delta=$ Solar declination angle $\left({ }^{\circ}\right)$, for the average day of August is then,

$$
\delta=23.45 \sin [0.9863(\mathrm{n}+284)]=13.5^{\circ}
$$

$\mathrm{n}=$ number of the day from the first of January, 228 for August.

Thus, the optimums tilt angle $(\beta)$ for a fixed solar collector at Abchway zone, Fayoum on August $=29.21-13.5=15.71^{\circ} \approx 15.7^{\circ}$ 
2. Drying chamber: The drying chamber was made of cubic wooden box with $0.60 \mathrm{~m}$ sides. In the middle of the drying chamber, wooden supports were fixed at two parallel sides of the drying chamber for placing the drying tray. The drying tray was made of an iron frame with $0.2 \mathrm{~cm}$ mesh stainless steel wire screen to permit drying passing throughout it. The drying tray was divided into three sections: the first section of the 3-mm, the second section of the $6-\mathrm{mm}$ and the third section of the $10-\mathrm{mm}$ onion slices thickness layers. The drying tray was inserted into (or removed from) the drying chamber through a hinged door $(0.55 \mathrm{~m} \times 0.35 \mathrm{~m})$, which was tightly sealed during the drying process. Inlet and outlet ducts with cone-shape were attached to the drying chamber to allow uniform air distribution inside it and delivers the exhaust air to the atmosphere. Two Orifice plates with $2.0 \mathrm{~cm}$ openings were used to measure the airflow rate. The exhaust air leaves the drying through the chimney, which was protected by a cover to prevent the ambient air from entering the drying chamber when the drying process was off. The drying chamber was completely insulated from the outside surfaces using a $2.5 \mathrm{~cm}$ thick glass wool to prevent absorbance of solar radiation and minimize the heat losses to the ambient atmosphere, especially during the drying process. The drying chamber was mounted on a wooden stand with $0.70 \mathrm{~m}$ sides.

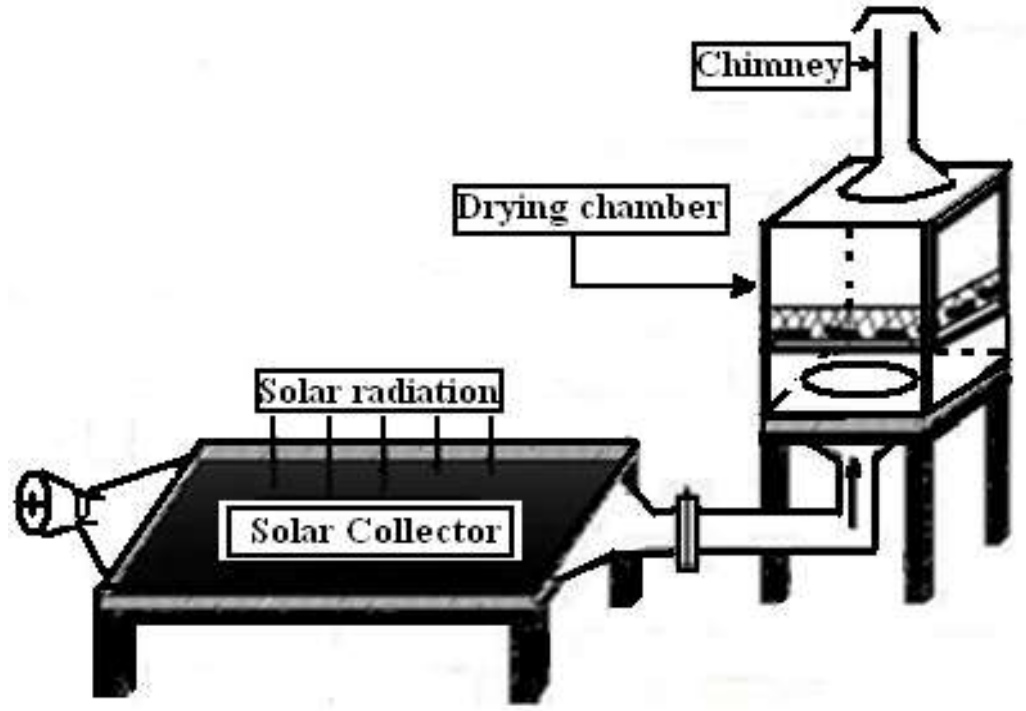

Fig. (1): Schematic Diagram of the Solar Drying System 


\section{B. Some physical properties of onion slices:}

Physical properties of onion slices (Giza 20 variety), which used in this study were determined, and presented in Table (1).

Table (1): Physical properties of onion slices samples.

\begin{tabular}{|c|c|c|c|}
\hline \multirow{2}{*}{ Properities } & \multicolumn{2}{|c|}{ Measured Value } & \multirow{2}{*}{ Average } \\
\cline { 2 - 3 } & maximum & minimum & Cylinderoid \\
\hline Shape & Cylinderoid & Cylinderoid & 81.5 \\
\hline $\begin{array}{c}\text { Initial moisture } \\
\text { content (\% w.b) }\end{array}$ & 82.4 & 80.6 & \\
\hline Mass $(\mathrm{g})$ & & & \\
3-mm & 6.0 & 5.6 & 5.8 \\
6-mm & 11.7 & 11.1 & 11.4 \\
10-mm & 19.2 & 18.6 & 18.9 \\
\hline Diameter $(\mathrm{cm})$ & 6.4 & 5.0 & 5.7 \\
\hline Surface area & 32.2 & 21.2 & 26.7 \\
$\left.(\mathrm{~cm})^{2}\right)$ & & & \\
\hline Volume $\left(\mathrm{cm}^{3}\right)$ & & & \\
3-mm & 9.5 & 6.7 & 8.1 \\
6-mm & 19.6 & 12.8 & 16.2 \\
$10-\mathrm{mm}$ & 32.2 & 21.2 & 26.7 \\
\hline Density $\left(\mathrm{g} / \mathrm{cm}^{3}\right)$ & 0.84 & 0.67 & 0.73 \\
\hline
\end{tabular}

\section{Measuring Instrumentation:}

1. Solar intensity: The hourly average total solar radiation flux incident on the horizontal and tilted surfaces was theoretically computed using the modified model of the American Society of Heating, Refrigerating and Air-Conditioning Engineers (ASHRAE, 1993).

2. Temperature measurement: The temperatures were measured using copper-constantan thermocouples. The thermocouples were calibrated at both boiling and freezing points. The measurements were conducted using digital thermometer (model Omega type J, USA). 
3. Airflow rate measurement: The airflow rate $\left(\mathrm{m}^{3} \cdot \mathrm{s}^{-1}\right)$ was measured using an orifice plates. The orifice plates were designed according to the International Standards Organization Standard No. ISO 5167-1980(E).

4. Relative humidity measurement: The air relative humidity (\%) of the inlet and outlet ducts of the dryer was measured using thermo-hygrometer (model 37200, OKTON).

5. Moisture content measurement: An electric balance and electric oven were used for weighing and drying samples to determine the moisture content of both fresh and dried onion slices before and during the drying process. The capacity of the electric balance was $1 \mathrm{~kg}$ with accuracy of \pm $0.01 \mathrm{~g}$. The samples were taken every two hour interval and dried on the electric oven at $70^{\circ} \mathrm{C}$ for $24 \mathrm{hrs}$. The moisture content of onion slices was calculated on both wet and dry bases.

D. Experimental Procedure: At the beginning of each experimental run, three different weights of each representative samples were used to determine the average initial moisture content of onions at different onion slices thickness layers $(3,6$ and $10 \mathrm{~mm})$. The obtained results showed that the average initial moisture content was $81.5 \%$ w.b (441.0\% d.b. At night, the drying system was left without humidifying and both of the air inlet and outlet ducts of each dryer were handily caped. For each drying run, the masses of labeled onion slices samples were measured initially and every two hours intervals daily. From this data, the final moisture contents of dried onion slices were determined. The total and actual drying times, moisture removed from onion slices were computed for each of the experimental run. The drying rate ( $g$ moisture removed. $\mathrm{hr}^{-1}$ ). ) is defined as the $1 \mathrm{~g}$ of moisture removed from the onion slice per hour. It was calculated by dividing the amount of moisture removed from the onion slices during the drying process by the actual drying time.

\section{E. Hourly Total Solar Radiation Flux Incident on a Horizontal and Tilted Surface:}

Most collecting devices associated with solar energy system are tilted at some angle with respect to the horizontal. The American Society of Heating, Refrigerating and Air-Conditioning Engineers (ASHRAE, 1993) has been modified an approach for computing the hourly average total solar radiation flux incident on a horizontal and tilted surfaces. The 
hourly total short-wave solar radiation $\left(\mathrm{I}_{\mathrm{T}}\right)$ flux incident on a tilted surface is the sum of three components: the direct solar radiation $\left(\mathrm{I}_{\mathrm{D}}\right)$, the diffuse sky radiation $\left(\mathrm{I}_{\mathrm{d}}\right)$ and the solar radiation reflected from the surrounding surfaces $\left(\mathrm{I}_{\mathrm{r}}\right)$ as follows:

$$
I_{T}=I_{D}+I_{d}+I_{r},\left(W \cdot m^{-2}\right)
$$

Each of the three components must be treated separately, and a set of steps are required for computing all the factors on the right side of equation (1) using Exile Computer Program.

1. The hourly average total direct solar radiation (ID): The intensity of the direct component was computed using the following equation:

$$
I_{D}=I_{D N} \cos (\boldsymbol{\theta}),\left(\mathbf{W} \cdot \mathrm{m}^{-2}\right)
$$

Where: $\mathrm{I}_{\mathrm{DN}}$ is the direct normal solar radiation, $\left(\mathrm{W} \cdot \mathrm{m}^{-2}\right)$ and $\theta$ is the angle of incidence between the incoming solar rays and a line normal (perpendicular) to the surface $\left(^{\circ}\right)$.

For any surface, the angle of incidence $(\theta)$ is related to the solar altitude angle $(\psi)$; the solar-surface azimuth angle $\left(\gamma_{\mathrm{ss}}\right)$ and the tilt angle of the surface $(\beta)$ as follows:

$$
\cos (\theta)=\cos (\psi) \cos \left(\gamma_{\mathrm{ss}}\right) \sin (\beta)+\sin (\psi) \cos (\beta),(-) . .(4)
$$

Where: $\psi$ is the solar altitude angle, $\left({ }^{\circ}\right) ; \gamma_{\mathrm{ss}}$ is the solar-surface azimuth angle, $\left({ }^{\circ}\right)$ and $\beta$ is the tilt angle of the surface from horizontal $\left({ }^{\circ}\right)$, which calculated from Equation (1).

The solar altitude angle was computed using the following formula:

$$
\sin \psi=\cos (\Phi) \cos (\delta) \cos (\dot{\omega})+\sin (\Phi) \sin (\delta)
$$

The solar-surface azimuth angle was computed as follows:

$$
\cos \gamma_{\mathrm{ss}}=[\sin (\Phi) \cos (\delta) \cos (\dot{\omega})-\cos (\Phi) \sin (\delta)] / \cos (\psi) \ldots(6)
$$

2. The hourly average direct normal solar radiation (IDN): At the earth's surface on a clear day, the hourly average direct normal solar radiation $\left(\mathrm{I}_{\mathrm{DN}}\right)$ was computed using the following equation:

$$
I_{D N}=A / \exp (B / \sin \psi),\left(W \cdot m^{-2}\right)
$$

Where: $\mathrm{A}$ is the apparent solar irradiation at air mass $=0.0,\left(\mathrm{~W} . \mathrm{m}^{-2}\right)$, for the average day of August $\mathrm{A}=1107 \mathrm{~W} \cdot \mathrm{m}^{-2}$ and $\mathrm{B}$ is the atmospheric extinction coefficient, $(B=0.201)$.

Values of $\mathrm{A}$ and $\mathrm{B}$ are varying during the year due to the changing of the earth-sun distance and the seasonal changes in dust and water vapor content of the atmosphere. 


\section{The hourly average solar radiation flux incident on a horizontal} surface (IDH): Because of the horizontal plane has a tilt angle of zero $(\beta=$ $0.0)$, consequently, $\cos \left(\theta_{\mathrm{H}}\right)=\sin (\psi)$, and then the hourly average direct solar radiation incident on horizontal surface $\left(I_{D H}\right)$ was calculated using the following equation:

$$
I_{D H}=I_{D N} \cos \left(\theta_{H}\right)=I_{D N} \sin (\psi),\left(W . m^{-2}\right) \ldots \ldots \ldots \ldots \ldots . . . .(8)
$$

4. The hourly average diffuse solar radiation $\left(\mathbf{I}_{d}\right)$ : The hourly diffuse solar radiation from a clear sky which falls on any surface can be calculated approximately using a simplified general relation as follows:

$$
I_{d}=\text { C IDN } F_{\text {ss, }}\left(\mathbf{W} \cdot \mathbf{m}^{-2}\right) \text {. }
$$

Where: $\mathrm{C}$ is the diffuse solar radiation factor, $(\mathrm{C}=0.122)$, and $\mathrm{F}_{\mathrm{ss}}$ is the angle factor between the surface and the sky, (-), which was calculated as follows:

$$
F_{\text {ss }}=(1+\cos (\beta)) / 2,(-)
$$

\section{The hourly average solar radiation diffusely reflected from the} ground $\left(\mathbf{I}_{\mathbf{r}}\right)$ : Ground-reflected radiation includes both the hourly diffuse solar radiation from a clear sky ( $\left.\mathrm{C} \mathrm{I}_{\mathrm{DN}}\right)$ and the hourly direct solar radiation incident on a horizontal surface $\left(\mathrm{I}_{\mathrm{DH}}\right)$. Thus, the hourly average total solar radiation incident on the ground was calculated as follows:

$$
\begin{aligned}
& I_{T H}=C_{\text {DN }} F_{\text {ss }}+I_{D N} \sin (\psi),\left(W \cdot m^{-2}\right) \\
& I_{T H}=I_{D N}\left(C F_{\text {ss }}+\sin (\psi)\right),\left(W \cdot m^{-2}\right) \ldots
\end{aligned}
$$

Where: $\mathrm{I}_{\mathrm{TH}}$ is the hourly average total solar radiation incident on the ground, $\left(\mathrm{W} \mathrm{m}^{-2}\right)$.

The hourly average ground-reflected diffuse solar radiation flux incident on any surface can be estimated as follows:

$$
\mathbf{I}_{\mathbf{r}}=\mathbf{I}_{\mathrm{TH}} \rho \mathrm{g} \mathbf{F}_{\mathrm{sg}},\left(\mathbf{W} \cdot \mathrm{m}^{-2}\right)
$$

Where: $\rho \mathrm{g}$ is the ground diffuse reflectance, $=0.40$ for August month and

$F_{s g}$ is the angle factor between the surface and the ground, (-).

The angle factor between the surface and the ground was calculated as follows:

$$
F_{\text {sg }}=(1-\cos (\beta)) / 2,(-)
$$

\section{F. Thermal Performance of Solar Collector:}

The thermal performance of the solar collector was estimated using the following equations: 


\section{Hourly average solar energy available on the collector surface ( $q_{a v}$}

): The hourly average total solar radiation available on the specific tilted surface of the solar collector was calculated using the following formula:

$$
\mathbf{q}_{\mathbf{a v}}=\mathbf{I}_{\mathbf{T}} \times \mathbf{A}_{\mathbf{C}} \text {, (Watt) }
$$

Where: $\mathrm{I}_{\mathrm{T}}$ is the solar radiation flux on the tilted solar collector, $\left(\mathrm{W} . \mathrm{m}^{-2}\right)$.

$\mathrm{A}_{\mathrm{C}}$ is the surface area of the solar collector, $\left(\mathrm{m}^{2}\right)$.

2. The Hourly Average Absorbed Solar Radiation ( $\left.q_{s}\right)$ : The hourly average total absorbed solar radiation by the solar collector absorber plate can be estimated from the following equation:

$$
\mathrm{q}_{\mathrm{s}}=\mathrm{q}_{\mathrm{av}}(\tau \alpha)_{\mathrm{av}}=\mathrm{I}_{\mathrm{T}} \times \mathrm{Ac}_{\mathrm{C}}(\tau \boldsymbol{\tau})_{\mathrm{av}},(\text { Watt })
$$

Where: $\mathbf{q}_{\mathrm{s}}$ is the hourly total absorbed solar radiation by the solar collector absorber plate $\left(\mathrm{W} \cdot \mathrm{m}^{-2}\right) ;(\tau \alpha)_{\mathrm{av}}$ is the optical efficiency, which can be calculated as follows:

$$
\begin{gathered}
(\tau)_{\mathrm{av}}=\tau_{\max }-0.00437 \exp ^{(0.0936(\theta-30))} . . \\
(\alpha)_{\text {av }}=\alpha_{\max }-0.00476 \exp ^{(0.0940(\theta-35)}
\end{gathered}
$$

Where: $\tau$ is the solar transmittance due to absorptance of the glass cover at the given tilt angle of the solar collector (-); $\alpha$ is the average absorptance for solar energy (-).

3. Useful heat energy gain $\left(Q_{\mathbf{u s}}\right)$ : The useful heat energy gain is calculated as follows:

$$
Q_{u s}=\mathbf{m ~ C p}\left(\mathbf{T}_{\mathbf{a o}}-\mathbf{T}_{\mathrm{ai}}\right) \text {, (Watt) }
$$

Where: $\mathrm{m}$ is the air mass flow rate, $(\mathrm{kg} / \mathrm{s}) ; \mathrm{Cp}$ is the specific heat of air, $\left(\mathrm{J} \mathrm{kg}^{-1} \cdot{ }^{\circ} \mathrm{C}^{-1}\right) ; \mathrm{T}_{\mathrm{ao}}$ and $\mathrm{T}_{\mathrm{ai}}$ are the outlet and inlet air temperatures of the solar collector, $\left({ }^{\circ} \mathrm{C}\right)$.

4. The thermal efficiency of the solar collector $\left(\eta_{\text {th }}\right)$ : The thermal efficiency of the solar collector is calculated as follows:

$$
\eta_{\text {th }}=Q_{\text {us }} / \mathbf{q}_{\text {av }}=\left[\mathbf{m ~ C p}\left(\mathbf{T}_{\text {ao }}-T_{\text {ai }}\right)\right] /\left(I_{T} \times \mathbf{A C}\right),(\%) \ldots(20)
$$

\section{G. Calculations of the solar radiations:}

The estimated data was calculated by Excel-2003 Software. These calculations include:

- A technique of estimating the hourly average total solar radiation flux incident on a south-facing solar collector using the meteorological and geographical parameters for Abshway zone (latitude and longitude angles are $29.21 \mathrm{~N}, 30.40^{\circ}$, respectively), Fayoum, Egypt on August. 
- The procedure for obtaining the thermal performance of a solar collector for a flat-plate flow-over-absorber.

\section{RESULTS AND DISCUSSIONS}

Estimation of solar radiation and influences of some factors on the performance of the solar collector can be discussed as follows:

\section{A. Calculated Parameters:}

1. Position of the Sun: The position of the sun relative to a plane of any particular orientation at any time can be described in terms of several angles (Duffie and Beckman, 1991). Some of these angles were calculated and the results are tabulated in Table (2). These angles were computed and used for the purpose of solar radiation estimations.

Table (2): Hour, altitude, zenith, solar azimuth and solar incidence angles for Abchway district, Fayoum, Egypt on August.

\begin{tabular}{|c|c|c|c|c|c|}
\hline $\begin{array}{c}\text { Time } \\
(\mathrm{h})\end{array}$ & $\begin{array}{c}\text { Hour } \\
\text { Angle } \\
(\omega)\end{array}$ & $\begin{array}{c}\text { Altitude } \\
\text { Angle } \\
(\psi)\end{array}$ & $\begin{array}{c}\text { Zenith } \\
\text { Angle } \\
\left(\theta_{\mathrm{z}}\right)\end{array}$ & $\begin{array}{c}\text { Azimuth } \\
\text { Angle } \\
\left(\gamma_{\mathrm{ss}}\right)\end{array}$ & $\begin{array}{c}\text { Incidence } \\
\text { Angle } \\
(\theta)\end{array}$ \\
\hline $6: 00$ & -90 & 8.2 & 81.8 & -100.4 & 81.9 \\
$7: 00$ & -75 & 20.9 & 69.1 & -93.1 & 69.1 \\
$8: 00$ & -60 & 33.7 & 56.3 & -85.3 & 56.3 \\
$9: 00$ & -45 & 46.4 & 43.6 & -76.1 & 43.6 \\
$10: 00$ & -30 & 58.6 & 31.3 & -62.9 & 31.5 \\
$11: 00$ & -15 & 68.8 & 21.2 & -40.8 & 21.2 \\
$12: 00$ & $0: 00$ & 73.4 & 16.6 & $0: 00$ & $0: 00$ \\
$13: 00$ & 15 & 68.8 & 21.2 & -40.8 & 21.2 \\
$14: 00$ & 30 & 58.6 & 31.4 & -62.9 & 31.5 \\
$15: 00$ & 45 & 46.4 & 43.6 & -76.1 & 43.6 \\
$16: 00$ & 60 & 33.7 & 56.3 & -85.3 & 56.3 \\
$17: 00$ & 75 & 20.9 & 69.1 & -93.1 & 69.1 \\
$18: 00$ & 90 & 8.2 & 81.8 & -100.4 & 81.9 \\
\hline
\end{tabular}

2. Hourly average incident total solar radiation: The hourly average total solar radiations incident on the horizontal and tilted surfaces $\left(15.7^{\circ}\right)$ were estimated and the results were illustrated in Fig. (2).The results indicated that, the hourly average total solar radiations incident on the 
solar collector surface almost clarified the same trend of that incident on the horizontal surface, while, the maximum values occurred at 12:00 noon. The daily average total solar radiations flux incident on the tilted surface was $7.32 \mathrm{kWh} . \mathrm{m}^{2}$. day $^{-1}$. Meanwhile, the daily average total solar radiation incident on the horizontal plane was $6.13 \mathrm{kWh} . \mathrm{m}^{-2}$.day ${ }^{-1}$. Consequently, the tilted surface of the solar collector inclined with an optimum tilt angle at noon $\left(15.7^{\circ}\right)$ for August month increased the solar energy by $19.41 \%$, because the tilt angle causes the beam-radiation to be perpendicular on the collectors' surfaces at and around noon.

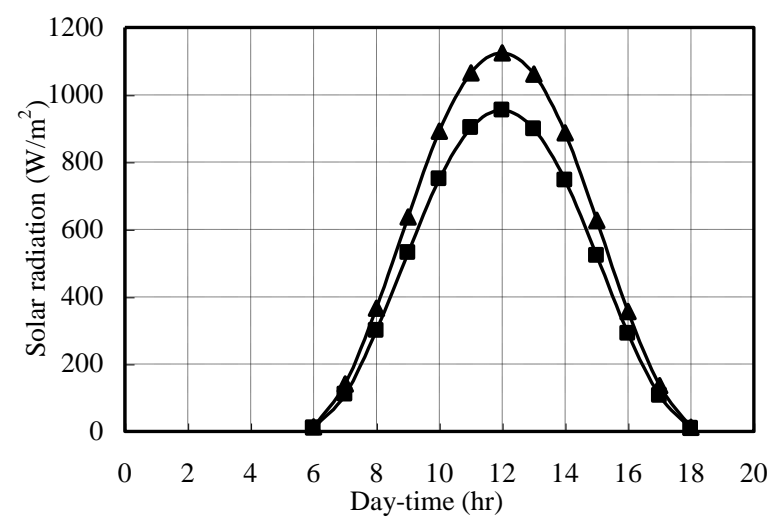

Fig.(2): Estimated values of hourly average solar radiation of Abchway zone, Fayoum, Egypt, at August, 2008

$\longrightarrow$ T. solar radiation on tilted serface(15.7 deg.)"

$\rightarrow-$ T.hourly solar radiation incedent on horizontal

\section{Hourly average solar radiation available, absorbed and gained:}

The hourly average solar radiations available, absorbed and gained with two different airflow rates $\left(2.4\right.$ and $\left.1.6 \mathrm{~m}^{3} \cdot \mathrm{min}^{-1}\right)$ were estimated and the results are illustrated in Fig. (3).The results indicated that the daily average total solar energy available on the tilted solar collector surface was $4.831 \mathrm{kWh}$. day ${ }^{-1}$. Meanwhile, the daily average total solar energy absorbed by the solar collector plate was $3.99 \mathrm{kWh}$. day ${ }^{-1}$ with absorption efficiency of $82.59 \%$. On the other hand, the results showed that the hourly average total useful energy gained $\left(q_{u s}\right)$ was directly related to some factors such as: solar intensity (I), difference between the outlet and 
inlet air temperatures of the solar collector and the mass of airflow rate (m). The obtained results revealed that, the hourly averages total useful heat energy gained by the air with airflow rate of $2.4 \mathrm{~m}^{3} \cdot \mathrm{min}^{-1}$ was relatively higher than that with the airflow rate of $1.6 \mathrm{~m}^{3} \cdot \mathrm{min}^{-1}$, since they were $2.53 \mathrm{kWh}$. day ${ }^{-1}$ and $2.25 \mathrm{kWh}$. day ${ }^{-1}$ for both airflow rates, respectively. The maximum values of the hourly average useful energy gained were achieved at 12:00 noon, because at this period the maximum solar intensity and higher difference between the outlet and inlet air temperatures occurred.

\section{Hourly average thermal efficiency of the solar collector: The} thermal efficiencies of the solar collector at two different airflow rates (2.4 and $\left.1.6 \mathrm{~m}^{3} . \mathrm{min}^{-1}\right)$ were calculated and the results are illustrated in Fig. (4). The obtained results indicated that the hourly average thermal efficiency of the solar collector almost clarified the same trend of the useful energy gained, where the maximum value occurred at 12:00 noon. The results revealed that the hourly average overall thermal efficiency for the solar collector tilted at the optimum angle with the higher airflow rate was $52.52 \%$, which is relatively higher than that $(46.66 \%)$ with the lower airflow rate. Consequently, the solar collector with the higher airflow rate increased the hourly average overall thermal efficiency of the solar collector by $12.56 \%$ as compared with that of the lower airflow rate. Thus, for the purpose of solar drying, the maximum solar energy collection is desired for a given month to maximize the amount of solar energy gained by the solar drying unit and consequently increasing its efficiency. 


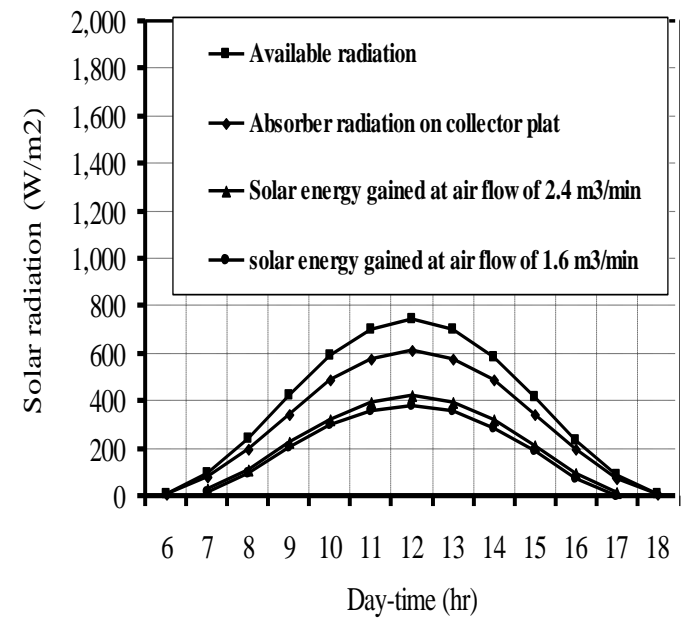

Fig.(3): Estimated values of hourly average solar radiation on the solar collector of Abshway zone, Fayoum, Egypt, at August 2008

\section{B. Measured Parameters:}

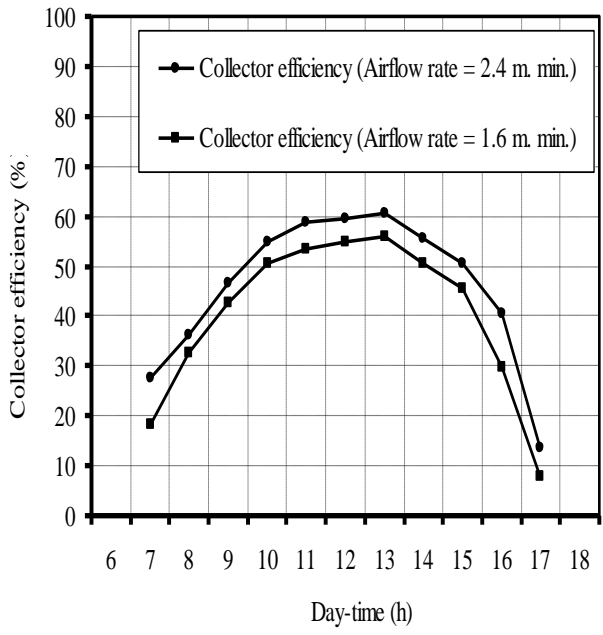

Fig.(4): Estimated values of hourly average solar collector thermal effiecency at different air flow rates of Abshway, Fayoum, Egypt, at August 2008

\section{Inlet and Outlet Air Temperatures of the Solar Collectors: The} hourly average ambient temperature $\left(\mathrm{T}_{\mathrm{a}}\right)$ for Abchway zone, Fayoum, Egypt and the outlet air temperature of the solar collector $\left(\mathrm{T}_{\mathrm{o}}\right)$ tilted at the optimum tilt angle $\left(15.7^{\circ}\right)$ was measured at two different airflow rates $\left(2.4 \mathrm{~m}^{3}\right.$.min. and $\left.1.6 \mathrm{~m}^{3} \cdot \mathrm{min}^{-1}\right)$ during the experimental period (August, 2008) and the results are graphically illustrated in Fig. (5).The results showed that, the outlet air temperature of the solar collector at two airflow rates were higher in most of the day-time (from 6:0 am to 8:0 pm) as compared with the corresponding values of the ambient temperature and almost take the same trend. The maximum values of the outlet temperatures for the solar collector with airflow rates of 2.4 and1.6 $\mathrm{m}^{3} . \mathrm{min} .{ }^{-1}$ were recorded to be $59.4{ }^{\circ} \mathrm{C}$ and $68.6{ }^{\circ} \mathrm{C}$, respectively, (at 2:0 0 $\mathrm{pm})$, whereas, the ambient air temperature reached to the maximum value of $38.2{ }^{\circ} \mathrm{C}$ (at 2:00 pm). The outlet air temperatures of the solar collector with airflow $1.6 \mathrm{~m}^{3} \cdot \mathrm{min}^{-1}$ were higher as compared with the corresponding values of the outlet temperatures with airflow rate of 2.4 $\mathrm{m}^{3}$.min. ${ }^{-1}$. At August (2008), the diurnally temperature cycle ranged from $25.8{ }^{\circ} \mathrm{C}$ to $38.2{ }^{\circ} \mathrm{C}$ during the time of the day, while the two airflow rates provided two drying air temperature cycles (day-time) ranged from 


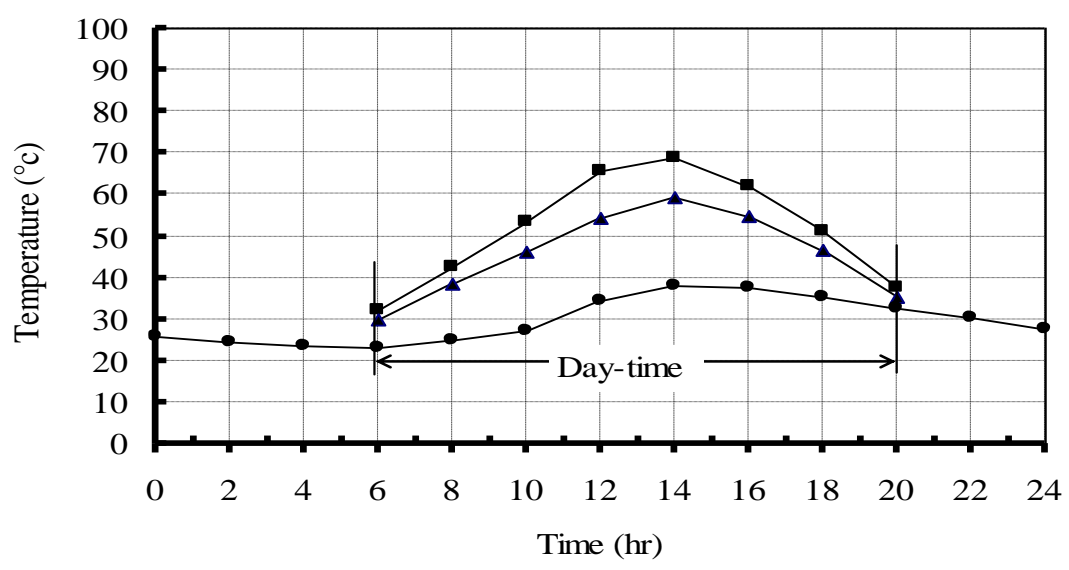

Fig.(5): Hourly average ambient temperature \& outlet air temperature of solar collector

$\rightarrow-$ Outlet air temperature (Airflow rate $=1.6 \mathrm{~m} . \mathrm{min}$.)

$\neg$ Outlet air temperature (Airflow rate $=2.4 \mathrm{~m} . \mathrm{min}$.)

$\neg$ Ambient air temperature ( C)

$29.9{ }^{\circ} \mathrm{C}$ to $59.3{ }^{\circ} \mathrm{C}$ and from 32.0 to $68.6{ }^{\circ} \mathrm{C}$ for the airflow rates of 2.4 $\mathrm{m}^{3}$.min. ${ }^{-1}$ and $1.6 \mathrm{~m}^{3} . \mathrm{min}^{-1}$, respectively. The results indicated that, the outlet temperature of the collector (drying air temperature) increased as the air flow rate decreased.

Two statistical equations were resulted from Excel-20o3, which described the relationship between the outlet air temperatures from the solar collector and the time number of the day-time (from $6 \mathrm{am}$ to $8 \mathrm{pm}$, which numbered 20). The following formulas are resulted:

$$
\begin{aligned}
& t_{1.6}=-0.6506 T_{n}{ }^{2}+17.588 T_{n}-53.382 \ldots \ldots \ldots \ldots \ldots \ldots . . . . . . . .2 R^{2}=0.95
\end{aligned}
$$

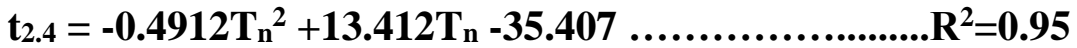

Where; $t_{1.6}$ and $t_{2.4}$ are the outlet air temperatures from the solar collector at air flow rates of 1.6 and $2.4 \mathrm{~m}^{3} / \mathrm{min}$, respectively, and $T_{n}$ is the hour number of the day-time (from 6 am to $20 \mathrm{pm}$ ).

2. Drying Rate of Onion Slices: Generally, in the drying process, the rate of moisture loss is very important, since it affects the changes in the product properties. Therefore, effecting of the three onion slices thicknesses and two airflow rates were investigated, in order to evaluate their effects on the drying-rate of onion slices.

2-a. Effect of onion slices thickness on the drying rate: Fig. (6) shows the moisture content of onion slices determined at two different airflow rates $\left(2.4\right.$ and $\left.1.6 \mathrm{~m}^{3} . \mathrm{min}^{-1}\right)$ for three different onion slices thicknesses $(3$, 6 and $10 \mathrm{~mm}$ ). It is clear that, the $3-\mathrm{mm}$ thick onion slice layer dried fastest at both airflow rates, followed by the $6-\mathrm{mm}$ and the $10-\mathrm{mm}$ thick 
layers. The finally average moisture content of onions slices was measured to be $6.8 \%$ (d.b.) and $7.7 \%$ (d.b.) at airflow rates of 1.6 and 2.4 $\mathrm{m}^{3} \cdot \mathrm{min}^{-1}$, respectively. This means that increasing the drying air temperature was sufficient to decrease the relative humidity, and thus, to increase the capacity of air to absorb moisture from the onion slices, especially at the end stage of the drying process. At airflow rate of 2.4 $\mathrm{m}^{3}$.min. ${ }^{-1}$ (Fig. 6-a), the moisture content of onion slices reached to its equilibrium $(7.7 \%$ d. b.) after actual drying time of approximately 10, 16 and $20 \mathrm{hr}$ for the 3,6 and $10 \mathrm{~mm}$ onion slices thicknesses, respectively, whereas at airflow rate of $1.6 \mathrm{~m}^{3} \cdot \mathrm{min}^{-1}$ (Fig. 6-b), the moisture content of onion slices reached to its equilibrium $(6.8 \%$ d. b.) after actual drying time of approximately 12,20 and $24 \mathrm{hr}$ for the same onion slices thickness, respectively.

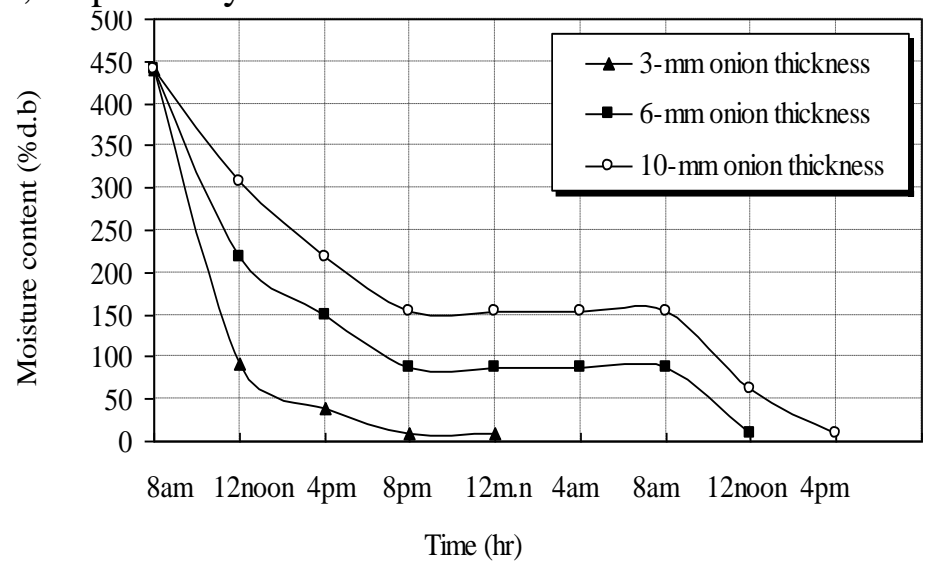

a) Airflow rate $=2.4 \mathrm{~m} / \mathrm{min}$.

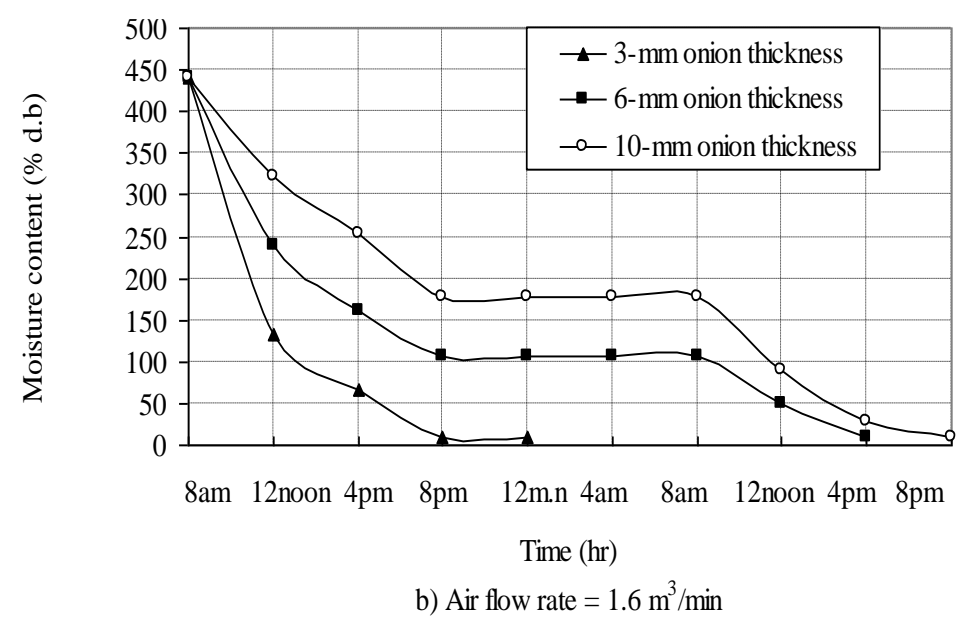

Fig.(6): Effect of onion slice thickness on the moisture content at verious air flow rates 
2-b. Effect of airflow rate on the drying rate: Fig. (7) shows the moisture content of onion slices determined at three onion slices thicklayers $(3,6$ and $10 \mathrm{~mm}$ ) for two different airflow rates $(2.4$ and 1.6 $\mathrm{m}^{3} \cdot \mathrm{min}^{-1}$ ). At the $3 \mathrm{~mm}$-thick onion slices thick-layer (Fig. 7-a), the moisture content reached its equilibrium after actual drying time of approximately 10 and $12 \mathrm{hr}$ at the airflow rates of 2.4 and $1.6 \mathrm{~m}^{3} . \mathrm{min}^{-1}$, respectively. At the $6 \mathrm{~mm}$ onion slices thick-layer (Fig. 7-b), the moisture content reached to its equilibrium after actual time of approximately 16 and $20 \mathrm{hr}$ at the airflow rates of $2.4 \mathrm{~m}^{3} \cdot \mathrm{min}^{-1}$ and $1.6 \mathrm{~m}^{3} \cdot \mathrm{min}^{-1}$ respectively. At $10 \mathrm{~mm}$ onion slices thick-layers (Fig. 7-c), the moisture content reached to its equilibrium after actual drying time of approximately 20 and $24 \mathrm{hr}$ at airflow rate of $2.4 \mathrm{~m}^{3} \cdot \mathrm{min}^{-1}$ and 1.6 $\mathrm{m}^{3} \cdot \mathrm{min}^{-1}$ respectively. It is clear that, the lower moisture content was obtained at the higher airflow as compared with the corresponding values, which obtained at the lower airflow rate at all onion slices thicknesses. This mean that, increasing the airflow rate was sufficient to increase the capacity of air to absorb more moisture from the onion slices. Pierce and Thompson (1980) indicated that the air flow rate is the most important factor in the design and operation of low temperature drying systems regardless of whether natural air or heated air is used.

2-b. Effect of airflow rate on the drying rate: Fig. (7) shows the moisture content of onion slices determined at three onion slices thicklayers $(3,6$ and $10 \mathrm{~mm}$ ) for two different airflow rates $(2.4$ and 1.6 $\mathrm{m}^{3} \cdot \mathrm{min}^{-1}$ ). At the $3 \mathrm{~mm}$-thick onion slices thick-layer (Fig. 7-a), the moisture content reached its equilibrium after the total drying time of approximately 10 and $12 \mathrm{~h}$ at the airflow rates of 2.4 and $1.6 \mathrm{~m}^{3} \cdot \mathrm{min}^{-1}$, respectively. At the $6 \mathrm{~mm}$ onion slices thick-layer (Fig. 7-b), the moisture content reached to its equilibrium after the total drying time of approximately 28 and $32 \mathrm{~h}$ at the airflow rates of $2.4 \mathrm{~m}^{3} . \mathrm{min}^{-1}$ and 1.6 $\mathrm{m}^{3}$.min. ${ }^{-1}$ respectively. At $10 \mathrm{~mm}$ onion slices thick-layers (Fig. 7-c), the moisture content reached to its equilibrium after the total drying time of approximately 32 and $36 \mathrm{~h}$ at airflow rate of $2.4 \mathrm{~m}^{3} \cdot \mathrm{min}^{-1}$ and 1.6 $\mathrm{m}^{3}$.min. ${ }^{-1}$ respectively. It is clear that, the lower moisture content was 
obtained at the higher airflow as compared with the corresponding values, which obtained at the lower airflow rate at all onion slices thicknesses. This mean that, increasing the airflow rate was sufficient to increase the capacity of air to absorb more moisture from the onion slices. Pierce and Thompson (1980) indicated that the air flow rate is the most important factor in the design and operation of low temperature drying systems regardless of whether natural air or heated air is used.

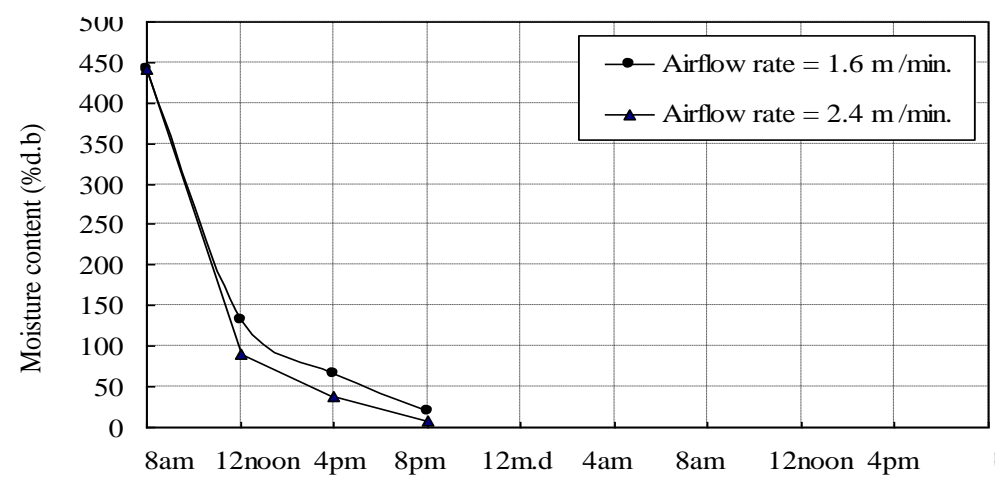

Time (hr)

a) Onion thickness $=3 \mathrm{~mm}$

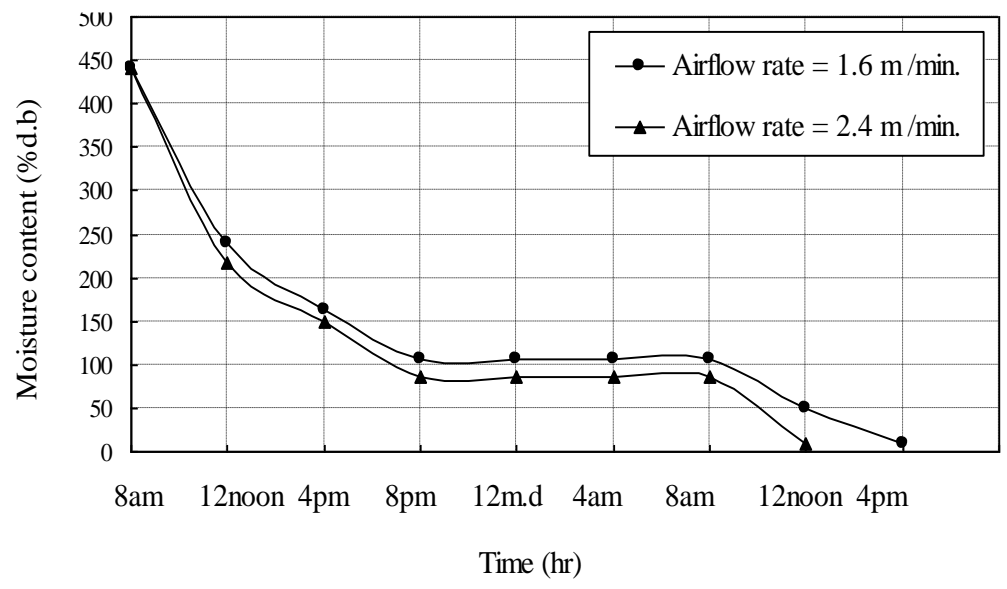

b) Onion thickness $=6 \mathrm{~mm}$ 


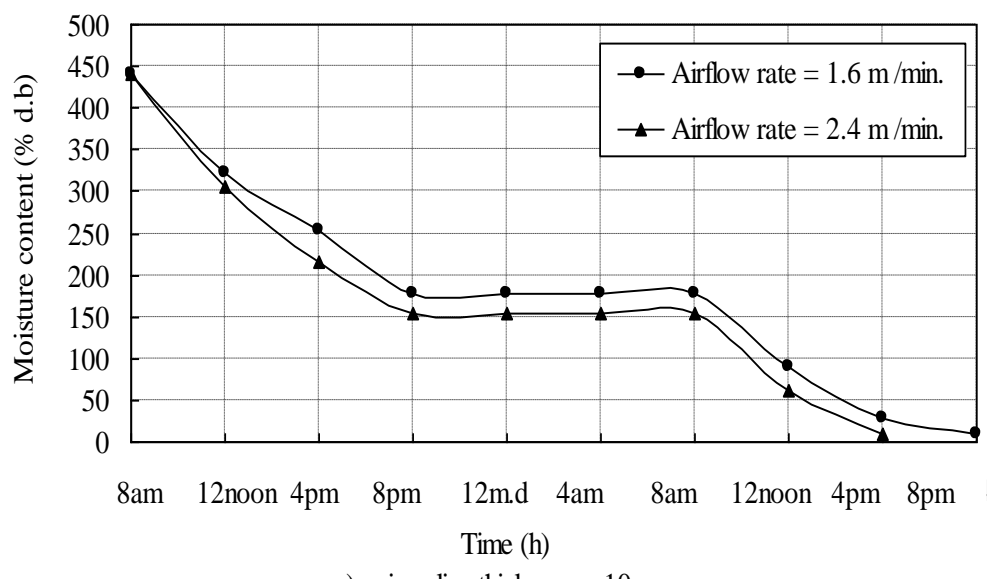

c) onion slice thickness $=10 \mathrm{~mm}$

Fig.(7): Effect of air flow rate on the moisture contient of onion slices at different thicknesses

2-c. Drying rate: The total and actual drying times, and moisture removed from onion slices were calculated to obtain the drying rate and the results are tabulated in Table (3). These calculations were made in order to compare the trends of the onion slices drying rate at various onion slices thicknesses and airflow rates. It is clear that the drying rate increased as both the onion slice thickness and airflow rate increased. Thus, the least time required for drying onion slices was for the $10-\mathrm{mm}$ slice thickness, followed by the 6-mm and 3-mm slices thicknesses at both airflow rates. The drying rate of $1 \mathrm{~g}$ of moisture from the onion slices ( 3, 6 and $10 \mathrm{~mm}$-thick layers) with the airflow rate of $1.6 \mathrm{~m}^{3} \cdot \mathrm{min}^{-1}$ was $4.02,5.34$ and $6.80 \mathrm{~g} / \mathrm{hr}$ respectively which was $17.45 \%, 22.94 \%$ and $16.97 \%$ lower than the corresponding rate $(4.87,6.93$ and $8.19 \mathrm{~g}$ moisture removed. $\mathrm{hr}^{-1}$ ) with the airflow rate of $2.4 \mathrm{~m}^{3}$. min. $^{-1}$, respectively. 
Table (3): Drying time and drying rate of onion slices at various airflow rates and onion slices thicknesses.

\begin{tabular}{|c|c|c|c|c|c|c|c|c|}
\hline \multirow{2}{*}{ Month } & \multirow{2}{*}{$\begin{array}{l}\text { Ainflow } \\
\text { rate } \\
\text { (minin) }\end{array}$} & \multirow{2}{*}{$\begin{array}{l}\text { Onion } \\
\text { slice } \\
\text { thickness } \\
\text { (mum) }\end{array}$} & \multicolumn{2}{|c|}{$\begin{array}{l}\text { Drying time } \\
\text { (hr) }\end{array}$} & \multicolumn{2}{|c|}{$\begin{array}{l}\text { Onion slice } \\
\text { weight }(g)\end{array}$} & \multirow{2}{*}{$\begin{array}{l}\text { Moisture } \\
\text { removed } \\
\text { (g) }\end{array}$} & \multirow{2}{*}{$\begin{array}{c}\text { Drying rate } \\
\text { (g moisture } \text { lit }^{1}\end{array}$} \\
\hline & & & Total & Actual & Initial & Final & & \\
\hline August & $2.4^{*}$ & $\begin{array}{l}3 \\
6 \\
10\end{array}$ & $\begin{array}{l}12 \\
28 \\
32\end{array}$ & $\begin{array}{l}10 \\
16 \\
20\end{array}$ & $\begin{array}{l}60 \\
120 \\
200\end{array}$ & $\begin{array}{l}11.3 \\
9.2 \\
36.2\end{array}$ & $\begin{array}{l}48.7 \\
110.8 \\
163.8\end{array}$ & $\begin{array}{l}4.87 \\
6.93 \\
8.19\end{array}$ \\
\hline$\left(25.8-28.2^{0} \mathrm{C}\right)$ & $1.6^{* \star}$ & $\begin{array}{l}3 \\
6 \\
10\end{array}$ & $\begin{array}{l}12 \\
32 \\
36\end{array}$ & $\begin{array}{l}12 \\
20 \\
24\end{array}$ & $\begin{array}{l}60 \\
120 \\
200\end{array}$ & $\begin{array}{l}11.6 \\
13.8 \\
36.7\end{array}$ & $\begin{array}{l}48.2 \\
106.2 \\
163.3\end{array}$ & $\begin{array}{l}4.02 \\
5.31 \\
6.80\end{array}$ \\
\hline
\end{tabular}

* Drying Temperature cycle of $29.9^{\circ} \mathrm{C}$ to $59.3^{\circ} \mathrm{C}$

${ }^{*+}$ Drying Remperature cycle of $32.0^{\circ} \mathrm{C}$ to $68.6^{\circ} \mathrm{C}$

\section{Statistical evaluation:}

Based on the effects of the introduced variables, each of them has its noticeable effect on the drying effectiveness. They have many varying individual importance, and their interactions would be expected to affect the drying effectiveness substantially. The effects of the individual variables (airflow rate, onion slice thickness and moisture removed), and their interactions on the drying rate of onion slices were statistically analyzed. A simple statistical program was developed utilizing SAS Statistical Pakage. The forward step-wise regression analysis was applied to arrive at a reasonable good best set of independent variables. The results of the regression model could be shown as follows:

$$
\text { Dr }=0.1066+1.596 \text { Af +0.431D ............ }\left(R^{2}=0.97\right)
$$

Where: Dr is the drying rate ( $\mathrm{g}$ moisture removed. $\mathrm{hr}^{-1}$ ), Af is the airflow rate $\left(\mathrm{m}^{3} \cdot \mathrm{min}^{-1}\right)$, and $\mathrm{D}$ is the onion slice thickness $(\mathrm{mm})$. Table (4) shows the sammary of forwared selection procedure for the dependent variable Dr.

Table (4): Sammary of forwared selection procedure for the dependent variable Dr for vertical direction

\begin{tabular}{|l|l|l|l|l|l|}
\hline Step & $\begin{array}{l}\text { Variable } \\
\text { In }\end{array}$ & Number & $\begin{array}{l}\text { Partial } \\
\mathrm{R}^{2}\end{array}$ & $\begin{array}{l}\text { Model } \\
\mathrm{R}^{2}\end{array}$ & Prop>F \\
\hline 1 & D & 1 & 0.7665 & 0.7665 & 0.0223 \\
2 & Af & 2 & 0.2049 & 0.9714 & 0.0189 \\
\hline
\end{tabular}


To evaluate the drying rate, a linear regression model was developed with both the observed and predicted drying rate. A graphical comparisons of the observed versus predicted values are presented in Fig.( 9), which have a coefficients of determination $\mathrm{R}=0.988$.

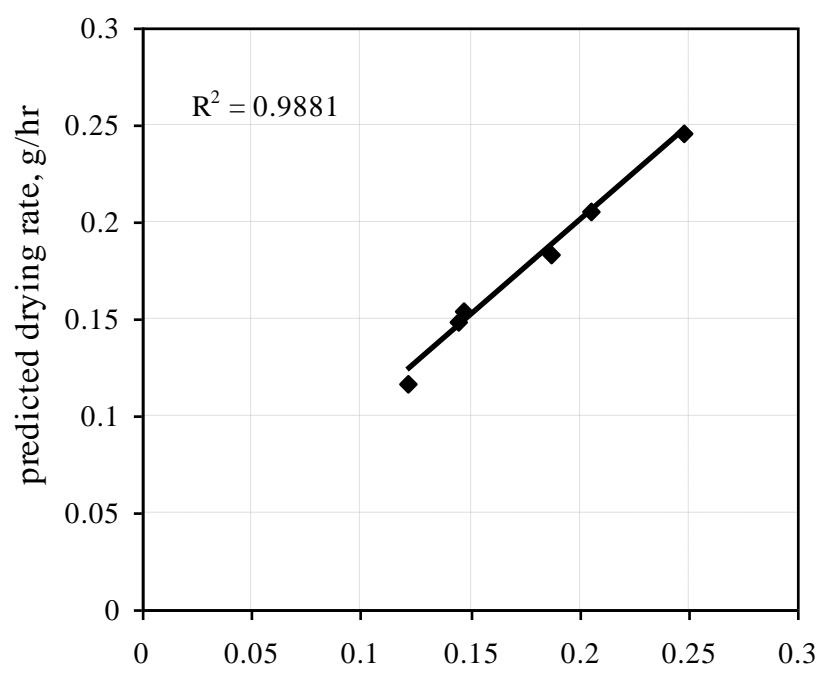

Observed drying rate, $\mathrm{g} / \mathrm{hr}$

Fig.(8): Observed vs. predicted dry ing rate

\section{CONCLUSION}

The solar collector surface increased the solar radiation incident on the horizontal surface by $19.41 \%$. The higher airflow rate $\left(2.4 \mathrm{~m}^{3} / \mathrm{min}\right)$ increased the hourly average overall thermal efficiency of the solar collector by $12.56 \%$ as compared with the lower airflow rate $\left(1.6 \mathrm{~m}^{3}\right.$ /min). So that, the best results of onion slices drying appeared with the higher air flow rate, this due to the high velocity of dry air with (2.4 $\mathrm{m} 3 / \mathrm{min}$ ), which, passed through the onion slices compared with the low velocity of the lower air flow rate. The effects of the individual variables (airflow rate, onion slice thickness and moisture removed), and their interactions on the drying index were statistically analyzed. The forward step-wise technique indicated that, the onion slice thickness (D) is the important parameter affecting on drying rate (Dr). 


\section{REFERENCES}

Agricultural Statistics (2006). Arab Republic of Ministry of agriculture and land reclamation. Economic Affairs Sector. (1): 57-62.

ASHRAE, (1993). Methods of testing to determine the thermal performance of solar collectors, American Society of Heating, Refrigerating, and Air-Conditing Engineers, Inc., New York, NY.

Al-Katary, H. S. (2000). Exhaust-air properties of onion drying. Misr J. Agric. Eng., 17(1): 173 - 184.

Duffie, J. A., and Beckman, W. A. (1991). Solar Engineering of Thermal Processes. The $2^{\text {nd }}$ Edition. 605 Third Avenue, New York, N.Y., Wiley-Interscience.

Essa, A. H. and Gamea, G. R. (2003). Physical and mechanical properties of bulb onions. Misr J. Agric. Eng., 20(3): 661 - 676.

Hall, C. W. (1980). Drying and storage of agricultural crops. The AVIPublishingInc., Westport, Connecticut, U.S.A.: 291-308.

Lewicki, P. P.; Witrowa, R. D. and Nowak, D. (1998-a). Effect of drying mode on drying kinetics of onion. Drying Technology. Warsaw Poland. 16(1): 59 -81.

Lewicki, P. P.; Witrowa, R. D. and Nowak, D. (1998-b). Effect of pretreatment on kinetics of convection drying of onion. Drying Technology. Warsaw Poland. 16(1): 83 -100.

Pierce, R. O. and Thompson, T. L. (1980). Management of solar and low temperature grain drying systems. Part II: Layer drying and solution to the over-drying problem. Transaction of the ASAE, 23(4): 10201023.

Sharma, P. K. and Nath, N. (1991). Dehydration characteristics ten onion cultivars. Lentensmittel-Wissenchaft-und-Technologies. 28(6): 348351.

Sharma, G, P.; Verma, R. C. and Pathare, P. B. (2005). Thin-layer infrared radiation drying of onion slices. J. of Food Engineering, 67(3): 361-366.

Yaldiz, O and Ertekin, C. (2001). Thin layer solar drying of some vegetables. Drying Technology, 19(3\&4): 583-597. 


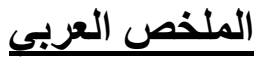

\section{أداء مجفف شمسي لشرائح البصل تحت الظروف المناخية لمحافظة الفيوم}

د. حمدى سالم السيد عبدالجليل" د. رجب اسماعيل أحمد مراد*"*

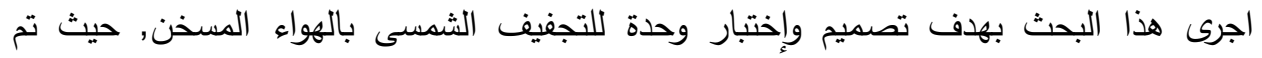

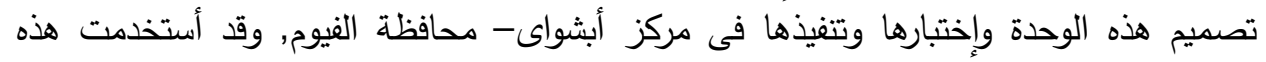

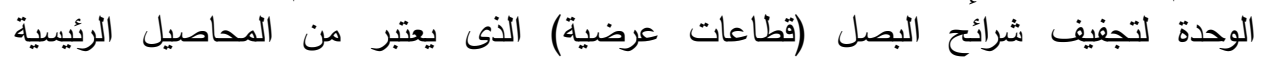

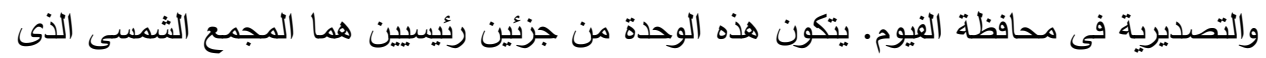

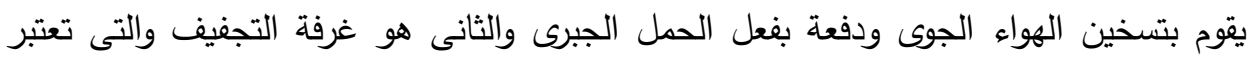

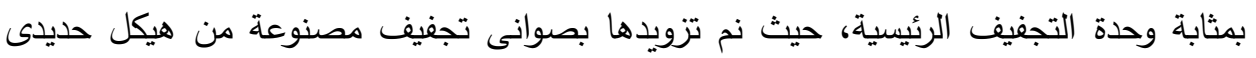

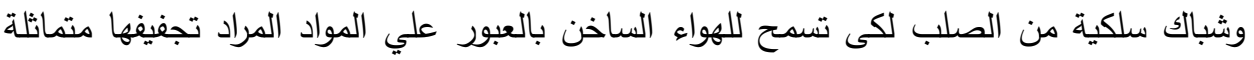

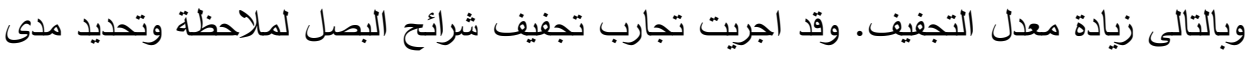

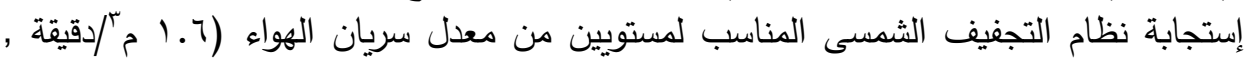

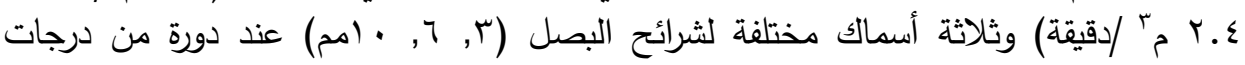

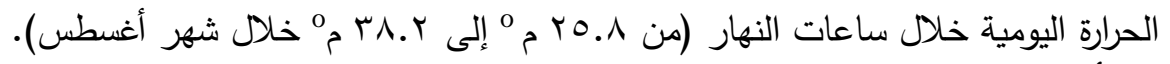
وقد أوضحت نتائج الدراسة مايلئ:

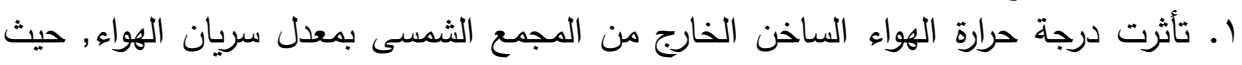

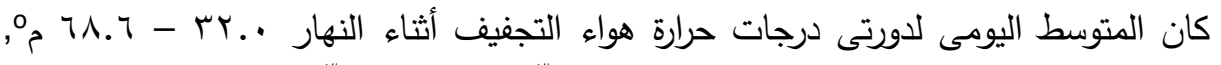

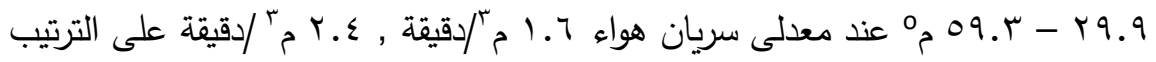

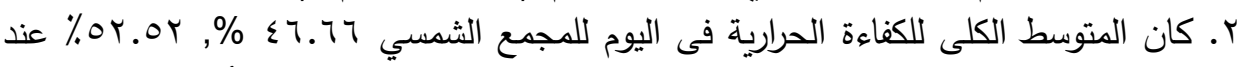

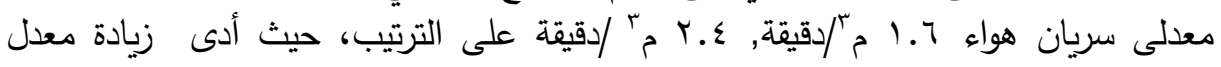

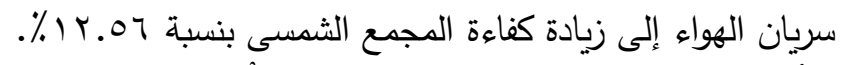

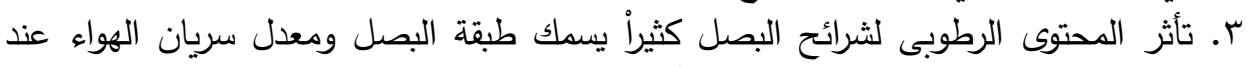

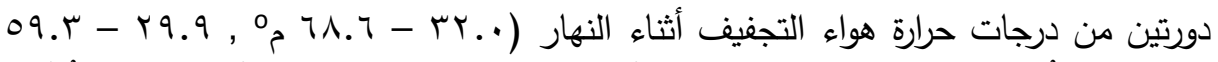

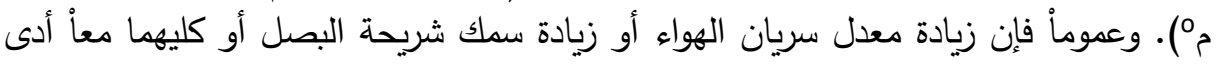
إلى تتليل الوقت المطلوب للتجفيف.

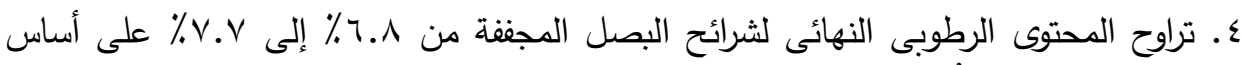

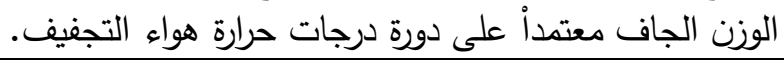

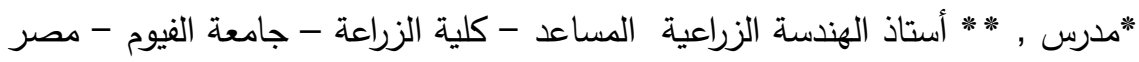


๑. أستتبطت معادلتين احصائيتين باستخدام برنامج Excel-2003 وذلك للتتبؤ بقيمة درجات

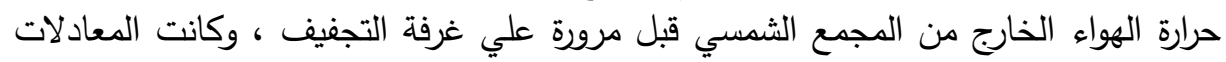

$$
\begin{aligned}
& t_{1.6}=-0.6506 T_{n}{ }^{2}+17.588 T_{n}-53.382 \ldots \ldots \ldots \ldots \ldots \ldots \ldots . . R^{2}=0.95 \\
& t_{2.4}=-0.4912 T_{n}{ }^{2}+13.412 T_{n}-35.407 \ldots \ldots \ldots \ldots \ldots \ldots \ldots . . . R^{2}=0.95
\end{aligned}
$$

حيث t.6 و t.4.4 درجتي حرارة الهواء الخارج من المجمع الثمسي عند معدل سريان هوائي قدرة

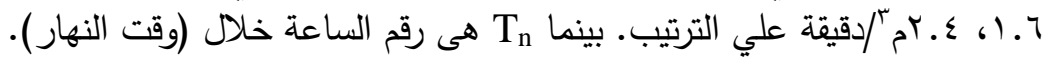

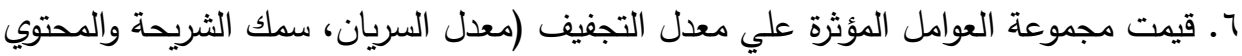

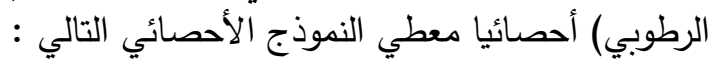

$$
\text { Dr = 0.1066 +1.596 AF + 0.431 D.............. (R (R = 0.97) }
$$

كما أنه باستخدام طريقة forward stepwise regression أوضحت أن التأثير الأكبر لسمك

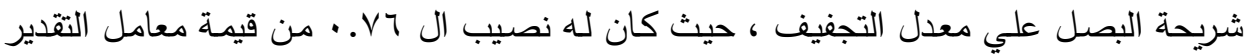
الذي بلغ V9. . ، ، أنظر الجدول التالي.

\begin{tabular}{|l|l|l|l|l|l|}
\hline Step & $\begin{array}{l}\text { Variable } \\
\text { In }\end{array}$ & Number & $\begin{array}{l}\text { Partial } \\
\mathrm{R}^{2}\end{array}$ & $\begin{array}{l}\text { Model } \\
\mathrm{R}^{2}\end{array}$ & Prop>F \\
\hline 1 & $\mathrm{D}$ & 1 & 0.7665 & 0.7665 & 0.0223 \\
2 & Af & 2 & 0.2049 & 0.9714 & 0.0189 \\
\hline
\end{tabular}

